\title{
The Political Economy of Arms Export Restrictions: The Case of Japan
}

\author{
ATSUSHI TAGO \\ Kobe University, Japan \\ tago@dragon.kobe-u.ac.jp \\ GERALD SCHNEIDER \\ University of Konstanz, Germany \\ Gerald.Schneider@uni-konstanz.de.
}

\section{Abstract}

The export of arms belongs to the most contested issues in democracies. In this article, we examine the economic repercussions of the recent easing of the Japanese arms exports restrictions. We develop a rational expectations argument to understand why some political events increase the income of the arms manufacturers, while other ones reduce it or have no effect at all. Event studies suggest that investors closely observe relevant political developments since stock prices of the six arms manufacturers companies reacted consistently to the announcements and leaks as to whether the arms export restrictions would be lifted or not.

\section{Introduction}

The export of arms belongs to the most contested issues in many democracies. This is particularly the case for the main losers of World War II, Germany and Japan, where discussions about the historical responsibility still frame public discussion about security issues considerably (Arrington, 2002). Legal constraints limit the discretion of policy makers and the defense sector further. Both nations have, however, despite these restrictions moved away from the strict ban on arms exports and thus one of the key legacies of the settlements of 1945 . While these reforms began in Germany already during the 1970s (Dembinski and Schuhmacher, 2005: 35), it only started towards the end of the Cold War in Japan.

Politicians typically defend the concessions towards the armament sector by pointing out the welfare gains that such exports create. The usage of this rhetorical figure masks that such activities have considerable redistributive consequences and that not least the investors in the arms industry might considerably profit from the 
softening of an arms export ban. In this article, we examine whether announcements or decisions that the Japanese arms restrictions policy shall be softened had any systematic effect on stock market performance of the main arms manufacturers in a country that still proudly cultivates its pacifist image.

Our political economy examination adds to a growing number of studies that explore the financial market repercussions of political events and the statements surrounding them (e.g. Bernhard and Leblang, 2006; Guidolin and La Ferrara, 2007, 2010; Herron et al., 1999; McGillivray, 2003; Schneider and Troeger, 2006). In this article, we will examine whether the positive or negative statements with regard to the further easing of Japanese export restrictions on arms sales changed the returns on investments in the main arms manufacturers. Admittedly, defense products are only a minor business for most Japanese arms manufacturers. This makes our inquiry into the economic repercussions of political statements a hard test, as one would not necessarily expect redistributive effects of political statements in an industry, which is economically marginal, but politically salient.

We develop an information efficiency argument and argue that markets will only care about unexpected and bold announcements. Our rational expectations framework suggests in this vein that statements or other developments that are unambiguously pointing towards a softening of the export restrictions will increase the returns on investment in the armament sector, whereas an unanticipated prolongation of the status quo will have the opposite effect. We rely on the event study approach, and thus a standard technique used in financial econometrics, to evaluate our hypotheses. The statistical tests show that traders only respond positively to an announcement if the expected policy change is clearly attractive for a specific firm and if the magnitude of these steps goes beyond the expectation of a piecemeal reform. The event studies further demonstrate that traders differentiate between the companies and that only those firms with exportable products profit from the announced policy changes. We discuss the implications of these findings for the political economy analysis of the Japanese defense sector.

\section{Development and structure of the Japanese arms export control policy}

One of the key foreign policy successes in Japanese politics after World War II has been building up the perception that pacifism is and will remain a core feature of the country. In reality, this stance has, however, evolved in a rather gradual fashion, as the development of the arms exportation restrictions clearly shows. Oros (2008: 90) traces the origin of this policy to 'postwar politics structured by the security identity of domestic antimilitarism' rather than to a 'culture of pacificism'. The restrictions started out with a partial ban in 1967 and a more comprehensive one in 1976. From 1953 to 1968 , arms manufacturers had exported arms, mainly ammunition, pistols, rifles, and land mines, to Brazil, Burma, India, Indonesia, the Philippines, South Vietnam, Taiwan, Thailand, and the United States (Nihon-Kikai-Kogyo-Rengokai [Association 
of Japanese Machine Industries], 2005: 36-7). Simultaneously, Japan had opted for a policy of indigenous production, kokusanka, of defense products. The sheltering of the armaments industry against foreign competition has come at a considerable economic price as 'military technology has simply moved faster than Japan's ability to catch up' (Green, 1995: 4). The combination of the arms export restrictions with a limited domestic demand has led to the development of a "boutique" defense industry' with often staggeringly high unit costs of production for weapons (International Institute for Strategic Studies, 2008: 455). ${ }^{1}$

The partial ban of 1967 reflects the international tensions during the Cold War as much as the influence of the anti-militaristic forces. Oros (2008: 91) goes as far as claiming that 'it was imposed by the United States and its allies'. Indeed, the Western Cold War alliance saw the exportation of pencil-rocket technology, which could be used for the development of militarily usable rockets, to Indonesia and Yugoslavia as a dangerous step. Prime Minister Eisaku Satō stated in the audit committee of the House of Representatives (Shīgiin) in April 1967 that the Japanese government prohibited the export of weapons to (1) communist states, (2) nations subject to an arms embargo under UN resolutions, and (3) nations involved in, or likely to be involved in, international armed conflict. This statement laid the foundation to what came to be known as 'The Three Principles for Restricting Arms Exports'.

The defense budget cuts following the first oil shock severely damaged the Japanese armaments industry. In December 1975, the Society of Japanese Aerospace Companies (SJAC) requested the government to permit and promote the exportation of airplanes that could be used for military purposes such as the US-1 Shinmaywa amphibian and the C-2 transport airplanes. However, on 27 February 1976, Prime Minister Takeo Miki extended the scope of the principles in the budget committee of the Shīgiin. This move, which Oros (2008: 109) partly motivates with upcoming Upper House (Sangiin) elections, amounted to an export ban in other areas than previously stipulated and the inclusion of 'arms-production-related equipment' into the restrictive policy. The economic effects of this ban were and are still considerable. From 1992 to 1996, Japan belonged to the group of countries in the global armament market with the smallest share of between $0 \%$ and $1 \%$ of the world-wide arms exports market (Keller and Nolan, 1997-8: 116).

However, exceptions to the ban were already made during the heydays of the New Cold War. This had especially to do with the technological leadership of the Japanese industry in some high-tech domains and the political clout these firms gained through this. The strength of Japanese companies in the development of dual-use technologies increasingly blurred in this period 'the borderline between commercial and military products' (Ikegami-Anderson, 1993: 340), allowing Japanese manufacturers to

1 The International Institute for Strategic Studies (2008: 455) mentions in this context the F-2 fighter with production costs of more than 100 million \$ per piece, while the F-16, which is the basis for the F-2, only costs around $\$ 35$ million. 
be involved in arms exports in an indirect way. Prime Minister Yasuhiro Nakasone, who entertained close personal ties to US President Ronald Reagan, authorized Japanese companies to transfer militarily relevant technology to its main Western ally (Shinoda, 2007: 32). Yet, the decision neither allowed the exportation of arms to the United States nor the joint weapon production with US companies.

The sale of computer-controlled milling machines by Toshiba Machine Corporation to the Soviet Union, which were used for the development of new submarine propellers, strained the relationship with the former occupying force considerably in 1987. This deal, which had already token place five years earlier, was in violation of the CoCom regime which prohibited the exportation of advanced technology to communist states during the Cold War. ${ }^{2}$ The dual-use potential of Japanese technology, the end of the Cold War, and a changing electoral landscape nevertheless allowed the government to reform its security policy and to gradually soften the arms exportations restrictions. Many of the policy changes went hand in hand with a strengthening of the alliance with the United States. This led in 1999 to the decision to co-develop a so-called navy theatre wide defense system with this partner nation. This step motivated the Japanese defense industry to lobby for the further easing of the three principles.

In February 2004, Keidanren, the powerful Japanese association of business organizations, met the leaders of the Liberal Democratic Party (LDP), formally pressuring them to lift the restrictions. ${ }^{3}$ The periodical publication of related policy proposals by this interest group had preceded these talks. ${ }^{4}$ The advisory board to Prime Minister Koizumi suggested in a policy report in April 2004 that the ban could at least partially be softened. The government finally relaxed the three principles on 9 December 2004, allowing Japanese companies to join US partners in the development of missile defense systems. The government also made it clear that the principles could be further eased and that military exports may be allowed on a case-by-case basis. ${ }^{5} \mathrm{~A}$ report by the Japanese Association of Machine Industries in 2005 revealed that many companies had an interest in such additional policy reforms. Twenty-nine out of 70 interviewed companies were interested in selling military-related technologies and

2 The Wassenaar Arrangement on Export Controls for Conventional Arms and Dual-Use Goods and Technologies with 33 signatory states replaced Coordinating Committee on Multilateral Export Controls (CoCom) regime in 1994.

3 According to Pekkanen and Kallender-Umezu (2010: 46-52), the Keidanren's requests of overturning the $1967 \mathrm{~s}$ arms export control policy were also intended to support Japanese space industry.

4 Keidanren published its policy proposals in 1995 (11 May), 2000 (19 September), and 2004 (20 July) under the LDP government. A similar proposal was made in 10 July 2010 under the DPJ government. This suggests that Keidanren lobbies governments of any orientation.

5 In 2006, the government allowed exporting three patrol vessels to Indonesia for the first time after the December 2004 policy shift. The government explained that this was for combating piracy around Indonesia and paid by the Japanese government. The patrol vessels were the same model of patrol ship used by the Japan Coast Guard and made by Sumidagawa-zosen, a small shipbuilding company. SRC NEWS, No. 74, January 2008 (http://www.srcj.or.jp/images/PDF/SRCNewsNo74.pdf). 
Table 1. Easing of arms exportations restrictions since 1983 to 2009

to/with the USA

fully relaxed in 1983
relaxed in 2004
relaxed in 2004, items can
be exported on a
case-by-case basis

to/with other countries

\author{
not relaxed \\ not relaxed \\ relaxed in 2004 , items can \\ be exported on a \\ case-by-case basis
}

Source: Ministry of Defense (so it will be as (2009). Briefing Memo on Defense Production, Technologies and the Export Restriction Policy (http://www.kantei.go.jp/jp/singi/ ampobouei2/dai6/siryou1.pdf).

products to other countries than the US, 17 answered to be 'only interested in the US' as an export market, and the remaining 24 firms did not respond to this question. ${ }^{6}$

Toshimi Kitazawa, the Defense Minister of Democratic Party of Japan (DPJ) government that came into power in 2009, was under strong pressure from the armaments industry to ease the principles further (Nikkei, 22 March 2010: M1). The major defense contractors officially met Kitazawa for the purpose of sharing their concerns on the current defense procurement policy and the arms sales ban on several occasions in 2010.7 Under continuing pressure from the industry, Kitazawa tried to convince the National Diet to consider easing the arms export restriction further (Asagumo, 14 November 2010). ${ }^{8}$ No further principal change has, however, taken place so far, and the principles remain valid and binding so that Japanese manufacturers cannot yet export their research-and-rescue amphibian planes, the C-2 transport airplanes, and other products. ${ }^{9}$ Table 1 summarizes the main developments since the 1980 .

As these policy developments show, the Japanese defense industry is especially in its international dimension largely a niche industry and for many companies a pure side-operation. The relative share of the profits stemming from defense contracts exceed $10 \%$ only in three of the six firms examined in this article. ${ }^{10}$ In the case of

6 According to a survey conducted in 2005 by the Japanese Association of Machine Industries, 29 out of 70 companies with some military-related production answered 'yes' as to a question if they have military-related technologies and products that can potentially be exported overseas.

7 Kitazawa had business meetings with major defense contractors including MHI, KHI, Mitsubishi Electric, Toshiba, IHI, and Shinmaywa in January/November/December 2010 and agreed to continue with such meetings in the future (see http://www.mod.go.jp/j/press/news and a newsletter of the Society of Japanese Aerospace Companies: http://www.sjac.or.jp/common/pdf/kaihou/ 201002/20100202.pdf).

8 http://www.asagumo-news.com/news/201011/101104/10110402.html.

9 According to the Reuters, Kitazawa told his US counterpart Robert Gates that Japan was studying ways to agree on the criteria for exports of the ship-based Standard Missile-3 Block IIA, which could be sold to some European countries (http://in.reuters.com/article/2011/06/03/ japan-usaidINL3E7H31ZK20110603).

10 MHI, KHI, Mitsubishi Electric, Toshiba, and IHI were the top five defense contractors with the Japanese government in the fiscal year of 2000; they were included in the analysis no matter how much they 
Toshiba, this ratio is even smaller than $2 \%$. Three firms with defense-production divisions belong to the largest industrial companies with total profits larger than 20 billion yen in 2000, two firms (IHI and KHI) are of medium size, and one enterprise (Shinmaywa) is a highly specialized producer of amphibian aircrafts with other non-military businesses. Note that most of the defense procurement was for the domestic market during the period under examination. If the companies wished to expand their armament production, they needed to convince the governments in the face of stagnating domestic demand to ease the exportation restrictions. Table 2 summarizes the information on defense contractors under consideration in this article.

The defense industry has tried to overcome the limits to growth that it has faced since the 1960 s with intensive lobbying. Especially the LDP, which was for a long time the hegemonic force in Japanese politics, has been the key target of these influence attempts. In 2006, Kokumin Seiji Kyokai, an LDP organization, received 30 million yen in 2006 from MHI. The top 11 industrial contractors provided 187 million yen in total in the same year with MHI, KHI provided 5 million yen each, MEC 18 million, IHI 11 million, and Toshiba 28.5 million; Shinmaywa provided a much smaller amount of 0.6 million yen. ${ }^{11}$ Hiroko Hatta, a Communist member of the Upper House, claimed that the top 20 defense contractors contributed 1.5 billion to the LDP from 1997 to 2001 in a meeting of the chamber's budget committee. Those 20 contractors obtained 4,737 billion yen in return from the Ministry of Defense. ${ }^{12}$

As Table $2 \mathrm{~B}$ shows, banks are the main shareholder of the six defense contractors under consideration. The Master Trust Bank of Japan (formed through investments from Mitsubishi UFJ Trust \& Banking Corporation, Nippon Life Insurance, Meiji Yasuda Life Insurance, and the Norinchukin Trust \& Banking Corporation) and the Japan Trustees Services Bank (founded by Resona Bank and Sumitomo Trust Bank with investment from Chuo Mitsui Trust Holdings) hold $10-15 \%$ of the shares of the six contractors, followed by other major Japanese banking and insurance corporations. There are only two foreign investors among the 30 top-shareholders listed in Table $2 \mathrm{~B}$. Given the close inter-linkages between politics, the financial sector, and the armament manufacturers in the Japanese defense procurement process, we would expect that markets are sensible towards plans to ease the weapon exportation controls, despite the marginal role the defense sector plays in the Japanese economy.

depended on defense contracts. Ten per cent of the profits stemming from defense production would be a justifiable threshold to assess whether the market considers a company vulnerable to the government decisions and non-decisions on the export restrictions. Among the top six to 20 arms producing companies, Shinmaywa was the only company with an income larger than $10 \%$ from defense products listed on the first section of Tokyo Exchange Market.

11 ' $475 \mathrm{MoD}$ OBs are obtaining an after retirement position in defense related companies and the top 15 defense contractors donated money to the LDP', Shimbun Akahata 2007.10.28 (morning issue).

12 'Defense Contractors paid 1 billion yen to the LDP during past 5 fiscal years', Shimbun Akahata 2003.6.17 (morning issue). 
THE POLITICAL ECONOMY OF ARMS EXPORT RESTRICTIONS

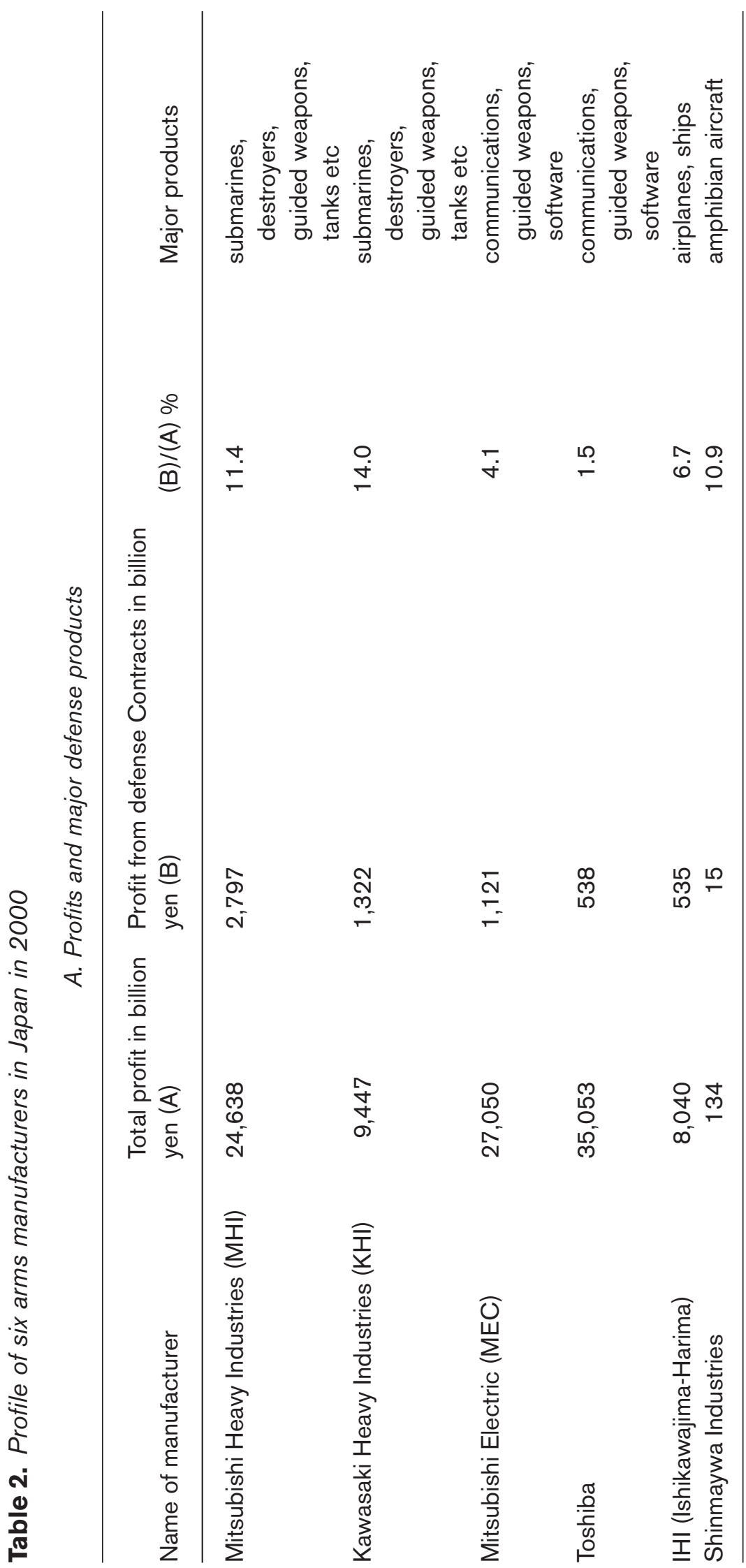




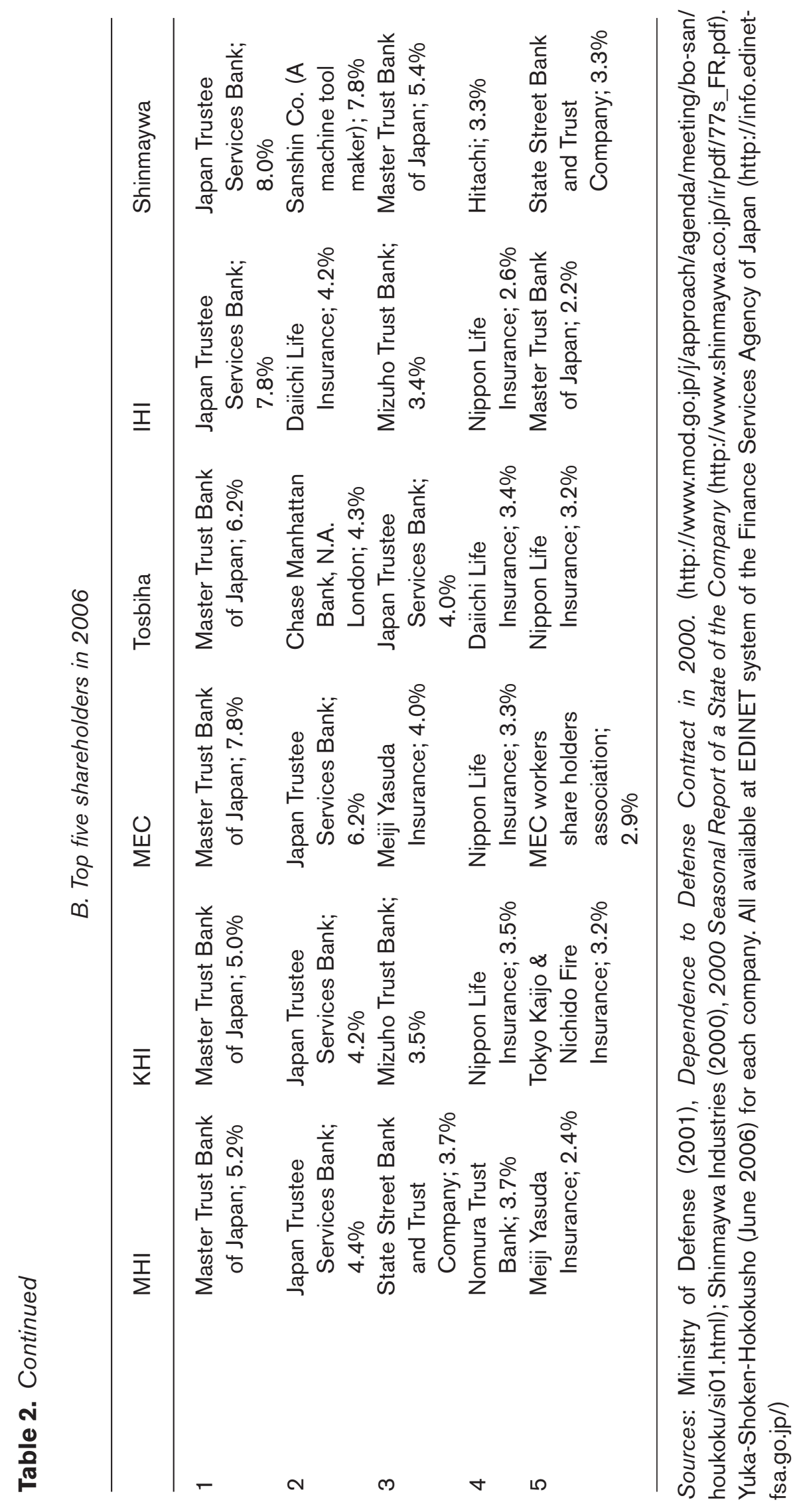




\section{Theory and hypotheses}

This article examines empirically how the political statements and decisions on the Japanese arms export restriction policies have affected the returns on investment in six armament producers. This query is in line with a growing body of evidence according to which politics affects markets considerably and that some announcements have substantial redistributive effects. Stigler and Friedland (1962) and Niederhoffer et al. (1970) were among the first researchers who systematically examined how politics affects markets. The main bulk of the subsequent studies examined how domestic events like elections, coalition politics, and cabinet reshuffles influence the performance of an individual security or of a particular market (e.g. Bechtel, 2009; Bernhard and Leblang, 2006). Lin and Wang (2007) show in this vein for instance that exchanging Prime Ministers in Japan did not affect financial markets. This non-result suggests that traders did not expect economically relevant policy reforms from these leadership reshuffles.

The study of how international political events and foreign policy decisions affect financial markets is less developed, despite Kerr's (1917) pioneering study. Most authors expect that war and other forms of political violence exert negative aggregate reactions. This is not least the case for severe terrorist attacks or tide-changing war events. Chen and Siems (2004) show for instance that the Nikkei index lost more than $6 \%$ on the trading day following the al-Qaida attacks on the United States on 11 September 2001. Zusman and Zusman (2006) demonstrate that counter-terrorism can have similar effects. While the killing of political leaders of Hamas went hand in hand with negative reaction on the Tel Aviv Stock Exchange, assassinations of military commanders ushered in positive responses. However, such tendencies do not remain stable over time. Eldor and Melnick (2004) show for instance in an analysis of the impact of terror attacks on stock market prices and exchange rates in Israel between 1990 and 2003 that these markets became desensitized to terror attacks after a while and continued to function efficiently after major terror incidents. Moreover, although armed conflict drives investors away from risky assets, the intensification of the political violence occasionally leads to a 'war rally', as such developments signal that a conflict might not be as costly as originally anticipated. Schneider and Troeger (2006) show for the conflict between Iraq under Saddam Hussein and the US-led alliance that growing hostilities led to an increase in the Dow Jones Industrial Index. In a broad evaluation of stock market reactions to conflict onsets, Guidolin and La Ferrara (2010) similarly demonstrate that war rallies are more common at the beginning of wars than negative market reactions.

Unanticipated political events and developments do not only influence the general market, but have also substantial redistributive effects. Herron et al. (1999) for instance show that the altering prospects of US presidential candidates in the 1992 elections have affected the stock returns of 15 out of 74 sectors. In the view of these authors, 'the proClinton bias of aerospace and defense is a function of Clinton's interest in industrial policy and worker training initiatives'. The developments in the era of George W. Bush might have changed the partisanship of the US defense sector. Halliburton, for which 
Vice President Cheney was the CEO from 1995 to 2000 , cashed in orders worth 11 billion dollars in the period from 2002 to 2002 in Afghanistan and Iraq. ${ }^{13}$

The defense sector, which almost completely depends on government orders, also responds to other political events. Bechtel and Schneider (2010) disclose that the summits of the European Union heads of state and government, who regularly convene within the European Council, can have considerable redistributive effects if these multilateral meetings end with a substantial decision. On average, the value of the sector increased by about 4 billion Euro following a summit decision that strengthened member states' common defense policy and security objectives. Similarly, the returns of the defense sector strongly respond to military expenditures. Capelle-Blancard and Couderc (2008) show that publication of financial statements and other firm-relevant events influence the performance of defense stocks.

Obviously, war events influence the stock market returns of the armament industry, too, although the effects are to some extent ambiguous. While an increase in the hostilities in the Korean War lowered the returns on investment in the armament and consumer goods industries, the development in the Vietnam War provoked growing returns (Kaun, 1990). Berrebi and Klor (2010: 541) document in an analysis of Israeli firms similarly 'that terrorism has a positive effect on the stock-market valuation of companies involved with defense, security or anti-terrorism products or clients, and a significantly negative effect on that of other companies'. According to DellaVigna and La Ferrara (2010), companies in highly corrupt countries violate arms embargoes more often than manufacturers that reside in states with lower levels of corruption. Chaney's (2008) analysis of the Iraqi bond yield spread reveals moreover that traders reacted to overtures towards Iran, but did not respond systematically to events which politicians portrayed as milestones towards democracy.

In this article, we develop, based on this emerging literature, a rational expectations model to account for the stock market reactions to defense policy statements and decisions on the Japanese arms exportation restrictions. We expect in line with the semi-strong version of the market efficiency thesis (Fama, 1965) that traders will absorb any information considered to be relevant for the profitability of a specific asset and that they know about its past performance on the market. The magnitude of a stock market reaction accordingly depends on how surprising a credible news report was. This hypothesis necessitates that we clearly differentiate between leaks and official statements in the empirical analysis. Media disclosures are by nature surprising, and we only need to assess whether the report is in favor or against the interests of the armament industry to anticipate either a positive or a negative effect. Official statements, by contrast, are often expected, not the least because of the piecemeal nature of Japanese policy reforms. The government cabinet typically decides on defense matters in December and announces a policy change or the preservation of the status quo as part of the review of Boei taiko (National Defense Program Guideline). Nevertheless, even anticipated policy changes

13 http://projects.publicintegrity.org/wow/resources.aspx?act=total (last consulted 3 August 2010) 
have market effects if the decided changes fall short of the expectations of the traders or if they anticipated a much tamer reform than the one finally delivered. In other words, the financial sector reacts negatively to announcements which dash its hopes for an easing of the arms exportation policy and positively to what it considers to be exceptionally good news in the form of more radical changes.

Obviously, the reactions depend on who is responsible for the policy announcement. As in other political systems, statements by the Prime Minister or the Defense Minister carry more credibility that the declared policy reforms will really be delivered than announcements by civil servants or junior ministers. However, this increased trustworthiness comes at the price of increasing leverage that high-level politicians possess and that may entice them to make 'spontaneous' remarks far away from the party line. One example was Prime Minister Abe, who had well-known credentials as a conservative, but who nevertheless showed some concern over the possible further easing of the arms export restrictions. We nevertheless expect that LDP politicians are more open towards a liberalization of the restrictions, not the least because of the close contacts this party has entertained over decades with the defense industry. If governments run by other parties reform the policy, the market reaction should, in other words, be more pronounced than the one attached to an equivalent move made by the traditional government party after World War II.

We also hypothesize that the market is capable to distinguish which companies are more affected by a policy shift. In our view, financial markets are structured through a complex division of labor among traders who specialize in different sectors and/or firms. This means for our analysis of the Japanese defense sector that we should mainly see positive reactions for those firms that have exportable products and that are therefore to increase their sales following the anticipated policy changes. Developments in Japanese space policy demonstrate this point. As Pekkanen and Kallender-Umezu (2010) show, major defense contractors such as MHI and MEC have played a critical role in the development of the 2008 Basic Space Law and 2009 Basic Space Plan, which in return has increased their international competitiveness by receiving government research funding and by benefiting from the national space projects.

Table 3 summarizes our hypotheses. Our rational expectations approach suggests that anticipation matters and the only surprising developments will find a direct reflection on the returns of a particular company. Furthermore, we hypothesize that the market differentiates between the companies and especially considers which firm offers exportable products. Furthermore, markets differentiate between reforms and stalemates and punish the market with negative developments if the political side prolongs the status quo against all expectations or dashes economic hopes that have previously been raised.

\section{Method and data}

Standard market models like the Capital Asset Pricing Model (CAPM) allow the researcher to calculate the expected return on an investment. To start with, for each 
Table 3. Theoretical framework and hypotheses

\begin{tabular}{lll} 
& Unexpected & Expected \\
\hline General policy change & $\begin{array}{c}\text { Positive reactions among } \\
\text { all firms } \\
\text { Positive reaction among } \\
\text { some firms }\end{array}$ & Small or no general reaction \\
Status quo prolongation & $\begin{array}{c}\text { Negative general/partial } \\
\text { reaction }\end{array}$ & Small or no general/partial reaction \\
\hline
\end{tabular}

sample stock asset $i$, the return on the asset for time period $t$ relative to the event, $R_{i t}$, is (Kothari and Warner, 2007: 8-9):

$$
R_{i t}=K_{i t}+\varepsilon_{i t}
$$

where $K_{i t}$ is the 'expected (i.e., normal)' return of an asset in period $t$, and $\varepsilon_{i t}$ the unexpected or abnormal returns. This immediately suggests that the abnormal return of the asset $\left(\varepsilon_{i t}\right)$ is the difference between the observed and the predicted return:

$$
\varepsilon_{i t}=R_{i t}-K_{i t}
$$

This difference is a direct measure of the unexpected change in the asset-holder wealth associated with the event, and thus the gain or loss on the investment in a specific asset that we cannot trace back to the market development.

The basic philosophy of this event study approach is to compare how an asset performed prior to and after an event. To this end, one needs to distinguish between the 'estimation window' and the 'event window'. In our case, the latter period of examination extends to five days, including two days prior and two days after the event. The empirical analysis establishes for the six companies under consideration a so-called market model. This regression analysis predicts the stock returns as a function of the log-transformed daily traded stock volume, the lagged log of the US dollar-yen exchange rate and the lagged log of Dow Jones Industrial Index.

We use the residuals, as suggested in equations (1) and (2), to evaluate our hypothesis. In order to identify the politically induced abnormal returns correctly, it is a convention to cumulate them over a predefined event window. Inaccuracies in assigning political events that occur on weekends or holidays to particular trading days demand the use of an event window larger than a single day. However, the error proneness, which we have already mentioned, as well as the detected persistence of volatility motivated us to include just a very few days within an event window.

A sufficiently large estimation window prepares the ground for estimating the parameters of the market model regression. The null hypothesis is that there are no significant cumulative abnormal returns during the event window. $t$-tests finally 
indicate whether we need to accept the null or not. ${ }^{14}$ If we can reject it, then the particular political event influences the returns on investments in the Japanese defense industry.

To identify political events that might affect the prices of major Japanese military industrial companies, this article relies on a systematic content analysis of related newspaper reports. More specifically, we use the database of the Nikkei, the best-known business newspaper in Japan. ${ }^{15}$ Indeed, it is the Nikkeithat issues the price index of Tokyo stock exchange. Furthermore, Nikkei owns a Bloomberg-like private TV broadcasting system with a solid reputation for its coverage of economic and business affairs. This database allows us to establish on which day a report on a relevant political decision or announcement was published and to evaluate whether this development might have affected the market evaluation of the defense industry.

More specifically, we used the Nikkei Telecom database to search when a political announcement either supporting or rejecting the easing of the arms restriction policies was made. ${ }^{16}$ Two graduate students searched articles by using key words such as 'lifting of arms export restriction' and 'three principles on arms export', and obtained 158 reports for the period from January 1999 to April 2010 from the database. We excluded editorial comments and open-ed contributions from our investigation. Articles which discussed the current Japanese position on arms sales but did not mention possible and imminent policy shift were also considered to be irrelevant. The application of these criteria led to the identification of six events which hinted at possible reforms or the preservation of the status quo in the Japanese arms exportation policy.

Table 4 summarizes in the light of our rational expectation conjectures the events that we consider in the analysis and the expected returns for each of the examined firms. The first event, reported in January 2000, is a spontaneous and therefore unexpected statement by the Defense Minister who stated his reluctance to relax the restrictions while there were strong pressures from the business community to lift the restriction. We expect that the market responds negatively to such events and that defense stock returns will be adversely affected. The second event happened almost three years later and consisted of an official announcement that the government starts to consider a partial reform for enabling joint arms production with the United States. As this event was expected as part of the Boei taiko review and constituted a very limited move of the government, we anticipate no or even a moderately negative effect.

A confirmation that the policy stance would at least partly be reformed followed one year later. The Koizumi administration decided to allow US-Japan joint production for Ballistic Missile Defense system and arms sales to foreign countries on a case-bycase basis for the purpose of fighting terrorism and combating piracy. The decision was

14 Even for the case of non-normally distributed errors, the application of a parametric $t$-test may suffice in large samples (cf. Corrado, 1989).

15 Asahi, Yomiuri, Mainichi, and Sankei are four other newspapers that provide nation-wide services in Japan but Nikkei has the best reputation among business people.

$16 \mathrm{http}: / /$ www.nikkeimm.co.jp/service/buisiness/telecom/index.html (the service is only provided in Japanese) 


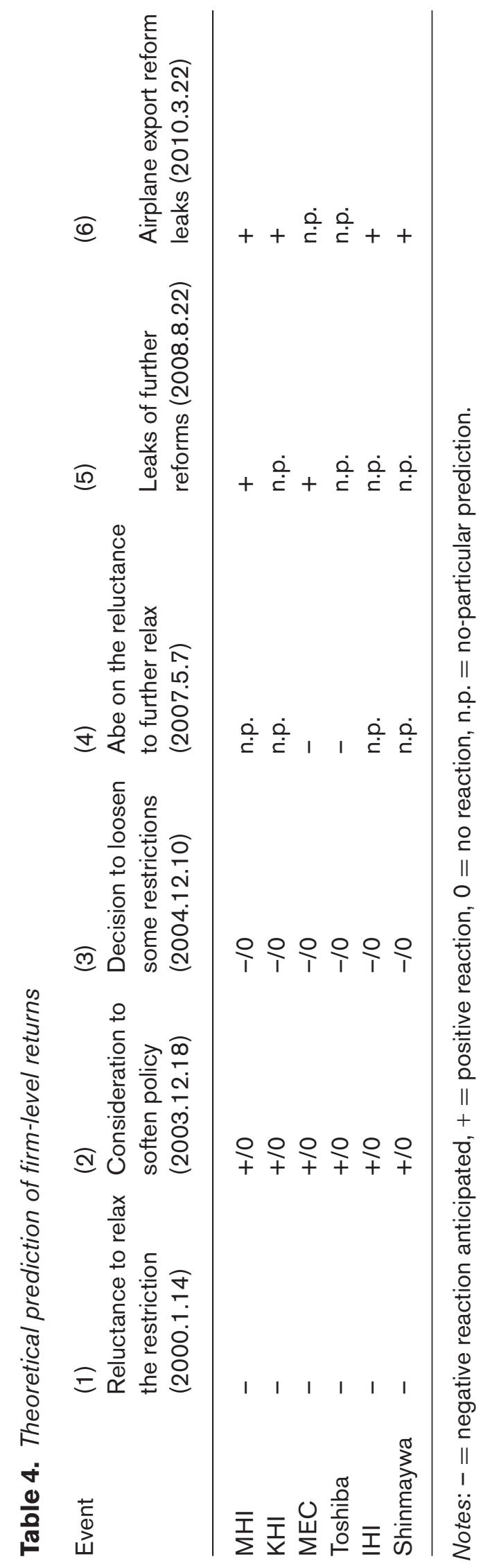


the first clear policy shift since 1983. Yet, as the government eased the restrictions only conditionally and still wanted to decide on a case-by-case basis for the limited purposes that could prevent exporting most of technologically advanced and competitive arms products, this was too small a policy shift to meet the lofty business and market expectation. ${ }^{17}$ The financial sector should have, in our view, reacted slightly negatively to this announcement as it was part of the Boei taiko review and thus represented a regular policy development.

The subsequent Japanese governments kept the tradition of piecemeal reform. Despite the widespread expectation in the industry that the government would allow more items to be exported, Prime Minister Shinzo Abe expressed - as indicated his reluctance to further ease the export regime in May 2007. ${ }^{18}$ Even though Abe was known to be a conservative and rather hawkish politician who entertained close contacts with the defense industry, he followed in this instance other priorities like education reform. ${ }^{19}$ We believe that his non-decision should have mostly affected MEC and Toshiba negatively. These firms would have needed further reforms to be able to export their high-tech defense products such as guided missiles and radars.

In August 2008, Nikkei leaked that the government would ease the export controls further as a part of the new Boei taiko by the end of 2009. ${ }^{20}$ The disclosure particularly referred to acceleration of the government's space defense project, for which two Mitsubishi companies (MHI and MEC) were developing key technologies (rocket launchers and satellite operation systems). In our view, the market should have been surprised by the news on the space program (but not by the news that the piecemeal reform of the export controls continued). The leak should thus only have affected these two companies positively. Finally, in March 2010, Nikkei reported the rumor that the new DPJ government might allow the export of airplanes manufactured by KHI-MHI-IHI groups and Shinmaywa. This leak came somewhat surprisingly since the DPJ was forming a coalition government with the Social Democratic Party, which is traditionally pacifist and should thus have been opposed to any change in the three principles policy. ${ }^{21}$ Yet, at the time we completed the empirical analysis (August 2010), no final decision was yet made, so that neither KHI, MHI, IHI nor Shinmaywa have

17 We can see the high expectation of Keidanren for lifting the restriction policy before the decision. On 20 July 2004, it issued policy recommendation for the government and pressured to change the export control policy. http://www.keidanren.or.jp/japanese/policy/2004/o63.html

18 This statement was made because the Defense Minister Kyuma and some other LDP diet members expressed their support for a further easing of the export control two days before during a speech at a symposium in Washington, DC.

19 Prime Minister Abe stepped out from office in September 2007. After his resignation, the less conservative Yasuo Fukuda formed a government; he quit in September 2008. The frequent government changes might be one reason for the lack of consistency in the reform of the arms exportation policy in the period under examination.

20 Due to the general election and historical defeat of the LDP government in September 2009, this prediction did not materialize (the DPJ government postponed the new Boei taiko for a year).

${ }_{21}$ The Social Democratic Party left the coalition government since after a disagreement with Prime Minister Hatoyama over the relocation of the US Futenma base in Okinawa. 
Table 5. Cumulative abnormal returns for six major japanese defense industries \pm two days from political decision/statement for or against relaxing policy of arms export restrictions

$2000.1 .14 \quad 2003.12 .18 \quad 2004.12 .10 \quad 2007.5 .7 \quad 2008.8 .22 \quad 2010.3 .22$

\begin{tabular}{lrrrrrr}
\hline MHI & $-0.46^{*}$ & $-1.29^{*}$ & $-1.13^{*}$ & 0.83 & $0.83^{*}$ & 0.13 \\
& $(-3.45)$ & $(-6.59)$ & $(-10.00)$ & $(1.70)$ & $(2.08)$ & $(0.89)$ \\
KHI & $-2.05^{*}$ & -1.89 & -0.54 & 0.90 & -0.10 & 0.63 \\
& $(-8.29)$ & $(-1.74)$ & $(-1.61)$ & $(0.63)$ & $(-0.23)$ & $(0.95)$ \\
MEC & $-1.05^{*}$ & $-1.99^{*}$ & $-1.98^{*}$ & -0.31 & $0.57^{*}$ & -0.27 \\
& $(-4.22)$ & $(-8.94)$ & $(-6.44)$ & $(-1.00)$ & $(2.06)$ & $(-0.90)$ \\
Toshiba & $0.78^{*}$ & $-1.78^{*}$ & $-1.50^{*}$ & -0.26 & -0.58 & $-0.87^{*}$ \\
& $(2.45)$ & $(-7.02)$ & $(-10.94)$ & $(-0.45)$ & $(-1.52)$ & $(-1.96)$ \\
IHI & $-2.13^{*}$ & $-1.57^{*}$ & $-0.87^{*}$ & 0.86 & -0.58 & $0.48^{*}$ \\
& $(-10.54)$ & $(-3.48)$ & $(-4.51)$ & $(0.38)$ & $(-1.37)$ & $(5.62)$ \\
\multirow{4}{*}{ Shinmaywa } & $-3.92^{*}$ & $0.40^{*}$ & $1.02^{*}$ & $0.73^{*}$ & -0.60 & $-0.99^{*}$ \\
& $(-7.85)$ & $(2.50)$ & $(5.82)$ & $(7.72)$ & $(-1.07)$ & $(-3.62)$ \\
\hline
\end{tabular}

Notes: Entries are cumulative abnormal returns and (in parentheses) t-test scores which were calculated by using the formula suggested by Kothari and Warner (2007: 10-11). The calculation refer to a five-day window with two pre-event days (2) and post-event days (2). Numbers colored in gray are the opposite to our theoretical prediction (see Table 3). With the exception of the two leaks where the timing of the event coincided with the publication day, reports on all events were published on the subsequent day. ${ }^{*} p<0.05$ (two-tailed significance tests).

sold planes to foreign buyers. We nevertheless expect positive financial market reactions from those two leaks since they were positive news for the defense industry and because these developments came unexpectedly.

\section{Results}

This section offers an analysis of how the market reacted to political statements on the Japanese arms restrictions policy. Table 5 displays the cumulative abnormal returns for six major Japanese defense industries. As these figures clearly show, the traders responded to the key political developments most often in the anticipated way. During the first phase from January 2000 to the end of 2004, the announcement by the Defense Minister expressing his reluctance to ease the three principles significantly affected the prices of the companies in our analysis with the exception of Toshiba, for which only $1.5 \%$ of its profits stem, as indicated, from defense products. The financial community originally nourished the idea that the conservative/pro-business LDP government would move away decisively from the restrictive arms exportation policy. The initial events, however, dashed such hopes; these non-decisions find their mirror image in the negative returns on the investment in the armaments industry.

The move away from this restrictive policy only led to some economic winners. Only Shinmaywa profited from the 2003 indication and 2004 decision to partially lift 
the ban on arms exports on a case-by-case basis. ${ }^{22}$ The returns for all other companies declined. This indicates that the market initially banked on more far-reaching reforms and was quite disappointed with the continuing piecemeal fashion in which subsequent Japanese governments moved away from the three principles or refused from changing this status quo altogether.

In the second phase from January 2005 to March 2010, the market selectively reacted to Nikkei's reports on the issue because the main concern for the market was which company would be actually allowed to export military products. MEC and Toshiba are two of the major electric companies and main contributors for production of guided weapons (missiles) and communication systems for the Self-Defense Forces. It is thus harder to obtain agreement to export their key products overseas on a case-by-case basis due to the 'war on terror' or 'combating piracy'. They needed further liberalization in order to export their products successfully. It is not surprising against this backdrop that Prime Minister Abe's announcement significantly decreased the returns on investments in the two companies. The market correctly assessed that the Abe's statement should only negatively affect those companies which would have profited from a less restrictive policy at this point in time. ${ }^{23}$

Only two firms, MHI and MEC, profited from the 2008 leak. This makes perfect sense if one considers that the Nikkei article emphasized that the government would start developing new defense technologies in outer space. This news was only relevant for these two firms as they are both prominent developers of space technologies, including launching a rocket with an asteroid explorer and a climate satellite. While $\mathrm{MHI}$ is in charge of production of space rockets, MEC is in charge of producing satellite technology (Pekkanen and Kallender-Umezu, 2010). ${ }^{24}$

The most recent event on 22 March 2010 affected the returns on the MHI, KHI, and IHI assets. ${ }^{25}$ The leak suggested that that the KHI's XC-2 transportation airplane and Shinmaywa's US-2 amphibian plane were the best candidates for passing case-bycase screening by the government. Such a disclosure should have been good news for both companies, and Shinmaywa as well as MHI and IHI produce engines and other key parts for the XC-2. However, the article suggested that Shinmaywa would need further investments for converting the planes for private usage. For instance, the US-2, which is designed for search-and-rescue missions of the Maritime Self-Defense Forces,

22 Shinmaywa succeeded with its first flight test of the US-2 amphibious aircraft in 18 December 2003 and delivered the second plane to the Maritime Self-Defense Forces in Iwakuni base in 7 December 2004 (http://www.shinmaywa.co.jp/products/list/aircraft_02.htm). Obviously, the technical successes contributed to the abnormal price rise of the company during the examined periods.

23 The non-significance of the CARs for Toshiba and MEC might indicate some limitations to the influence of Prime Minister Abe. However, it must be emphasized that the market correctly distinguished those companies that would be negatively affected by the announcement from other companies that would not.

24 IHI and Toshiba have outer space division as well but they are separated companies so that the news did not positively affect their stock prices.

25 The CARs for MHI and KHI fail to reach statistical significance. 
Table 6. Gains and losses in market capitalization (scale in yen)

\begin{tabular}{|c|c|c|c|c|c|c|}
\hline & $\mathrm{MHI}$ & $\mathrm{KHI}$ & MEC & Toshiba & $\mathrm{IHI}$ & Shinmaywa \\
\hline & 0.0 & -13 & billion & & & \\
\hline 18 & -1 & -11 & -15.7 billion & -25.1 & -7 & \\
\hline 004.12 .10 & -10.4 billion & -2.9 billion & -15.6 billion & .0 billion & -3.5 billion & 0.3 billion \\
\hline & & & - & on & lion & lion \\
\hline & & -1 & on & -7 & -2 & \\
\hline 2010.3.22 & 3.8 billion & 3.1 billion & -2.8 & -10.1 billion & Illion & -0 \\
\hline
\end{tabular}

Note: All related information to calculate the change in market capitalization is obtained from the Nikkei Money Basic (http://markets.nikkei.co.jp/)

in early 2011 did not yet have a certificate from the Ministry of Land, Infrastructure and Transportation, which is required in order to sell the airplane on the private market. Furthermore, even though the Shinmaywa plane is expected to be used for fire-fighting, water-tanks must be newly developed and installed. In short, the article was not so positive as to Shinmaywa's US-2 airplane and this could be a reason why the company did not profit from the leak in contrast to the other armament producers.

As Table 6 demonstrates, the redistributive effects of these developments are not negligible. The first examined event, the reluctant statement by the Defense Minister, amounted to losses between 5.3 (MHI) and 13 billion yen of market capitalization (KHI). Market capitalization, which stands for the value of a corporation, is calculated by multiplying the stock price and the number of outstanding shares. The following gains and losses of market capitalization resulted from the second event: Toshiba $(-25.1$ billion yen) and MEC ( -15.7 billion yen), Shinmaywa ( 0.2 billion yen). Shinmaywa also minimally gained 0.3 billion yen in market value as a consequence of the third event, while Toshiba's capitalization losses amounted to at least 19 billion yen. Prime Minister Abe's surprisingly negative policy stance led to losses for MEC and Toshiba 2.9 billion and 5.5 billion yen respectively in market capitalization. The fifth event, by contrast, was associated with gains of 7.7 billion (MHI) and 3.8 billion yen (MEC). Similar but smaller gains could be observed for MHI, KHI, and IHI with regard to the sixth event, while the negative return on the Shinmaywa asset was 0.3 billion yen of capitalization.

These figures illustrate that that the market carefully assesses political developments and that returns on investments in the Japanese defense industry closely reflect these trends. This suggests that market traders analyze the economic and political news in this area and build rational expectations of what the announced policy changes imply for the profitability of a particular asset.

\section{Conclusion}

This article provides additional empirical evidence to support the existing argument which connects political decision-making processes to the ups and downs 
of the defense industry on the stock market (e.g. Schneider and Troeger, 2006; Bechtel and Schneider, 2010). While previous studies suggested that a change of political leadership in Japan did not affect financial markets (Lin and Wang, 2007), this article shows that markets are nevertheless influenced by political announcements and decisions which directly affect the ordering book of the industry. The analysis particularly shows that mainly surprising news in the form of leaks that lead to increases in the return of armament producers. However, investors carefully consider whether a producer will really be ready for conquering foreign markets once the anticipated policy changes become effective. The defense sector did not only react to positive news. The announcement by Defense Minister Ohno in January 2000 that the policy would not be relaxed was unsurprisingly met by a negative market reaction.

The analysis suggests more generally that financial market reactions allow us to measure the redistributive effects of real and of attempted policy reforms. The failure of many studies to obtain clear evidence in favor of the thesis that some investors profit from increased tensions in the international scene is mostly due to the high level of temporal aggregation in which these studies are conducted. The analysis suggests that security policy measures have economically modest but politically salient economic repercussions also for a still largely pacifist society like the Japanese one. Finally, econometric analyses of financial markets increase the transparency of the political and economic decision-making process. The demonstration of how much investors into the armaments industry profit from individual political decisions making helps to qualify a discussion which frequently fluctuates between demonization and extenuation.

\section{About the authors}

Atsushi Tago (1976) is Associate Professor of International Relations at Graduate School of Law, Kobe University (since 2007 July) and Associate Editor of International Relations of the Asia-Pacific (since 2009). Before joining the faculty at Kobe, he studied in the University of Tokyo (received his Ph.D. in 2007) and the University of Michigan (as a visiting scholar from 2002-04). Tago was also a visiting scholar at the UC San Diego from October 2010 to September 2012. He has published several articles on military coalitions and alliances, American use of force and political mass killing. His book on US multilateral and unilateral military actions was published in Japanese from Chikura-shobo in 2010.

Gerald Schneider (1962) is Professor of International Politics at the University of Konstanz, Germany, since 1997 and Executive Editor of European Union Politics since 2000. Before joining the faculty at Konstanz, he was a Professor of Political Science at the University of Stuttgart. Schneider has also been visiting scholar at Kobe University in 2010 and program co-chair of the 5oth annual convention of the International Studies Association in 2009. He has published around 140 articles in international journals and volumes on decision making in the European Union, the causes and consequences 
of political violence and a broad range of other topics. Recent papers have appeared in Conflict Management and Peace Science, European Political Science, International Interactions, and International Organization.

\section{References}

Arrington, Aminta (2002), 'Cautious Reconciliation: The Change in Societal-Military Relations in Germany and Japan since the End of the Cold War', Armed Forces \& Society, 28(4): 531-54.

Bechtel, Michael M. (2009), 'The Political Sources of Systematic Investment Risk: Lessons from a Consensus Democracy', Journal of Politics, 71(2): 661-77.

Bechtel, Michael M. and Gerald Schneider (2010), 'Closely Watched Summits: How Stock Markets React to Multilateral Diplomacy on the EU Defence Sector', International Organization, 64(2): 199223.

Bernhard, William and David Leblang (2006), Democratic Processes and Financial Markets: Pricing Politics, New York: Cambridge University Press.

Berrebi, Claude and Klor, Esteban F. (2010), 'The Impact of Terrorism on the Defence Industry', Economica, 77: $518-43$.

Capelle-Blancard, Gunther and Nicolas Couderc (2008), 'What Drives the Market Value of Firms in the Defense Industry?', Review of Financial Economics, 17:14-32.

Chaney, Eric (2008), 'Assessing Pacification Policy in Iraq: Evidence from Iraqi Financial Markets', Journal of Comparative Economics, 36(1): 1-16.

Chen, Andrew H. and Thomas F. Siems (2004), 'The Effects of Terrorism on Global Capital Markets', European Journal of Political Economy, 20: 349-66.

Corrado, Charles J. (1989), 'A Nonparametric Test for Abnormal Security-Price Performance in Event Studies', Journal of Financial Economics, 23: 385-95.

Della Vigna, Stefano and Eliana La Ferrara (2010), 'Detecting Illegal Arms Trade', American Economic Journal: Economic Policy, 2(4): 26-57.

Dembinski, Matthias and Barbara Schuhmacher (2005), 'Wie Europa dem Rüstungsexport Schranken setzt. Von der Zusammenarbeit europäischer Regierungen zum europäischen Regieren', Frankfurt/M: HSFKReport 9/2005, http://cgi.hsfk.de/fileadmin/downloads/report_demb_0106.pdf (last consulted 14 July 2010).

Eldor, Rafi and Rafi Melnick (2004), 'Financial Markets and Terrorism', European Journal of Political Economy, 20: $367-86$.

Fama, Eugene (1965), 'The Behavior of Stock Market Prices', Journal of Business, 38(1): 34-105.

Green, Michael J. (1995), Arming Japan: Defense Production, Alliance Politics, and the Postwar Search for Autonomy, New York: Columbia University Press.

Guidolin, Massimo and Eliana La Ferrara (2007), 'Diamonds Are Forever, Wars Are Not: Is Conflict Bad for Private Firms?', American Economic Review, 97(5): 1978-93.

Guidolin, Massimo and Eliana La Ferrara (2010), 'The Economic Effects of Violent Conflict: Evidence from Asset Market Reactions', Journal of Peace Research, 47(6): 671-84.

Herron, Michael C., James Lavin, Donald Cram, and Jay Silver (1999), 'Measurement of Political Effects in the United States Economy: A Study of the 1992 Presidential Elections', Economics and Politics, 11(1): $51-79$.

Ikegami-Andersson, Masako (1993), 'Japan: A Latent but Large Supplier of Dual-Use Technology', in Herbert Wulf (ed.), Arms Industry Limited, Oxford: Oxford University Press, pp. 320-44.

International Institute for Strategic Studies (2008), The Military Balance 2009, Abingdon: Routledge.

Kastellec, Jonathan P. and Eduardo Leoni (2007), 'Using Graphs Instead of Tables in Political Science', Perspectives on Politics, 5(4): 755-71.

Kaun, David E. (1990), 'War and Wall Street: The Impact of Military Conflict on Investor Attitudes', Cambridge Journal of Economics, 14(4): 439-52.

Keller, William W. and Janne E. Nolan (1997/8), 'The Arms Trade: Business as Usual?', Foreign Policy, 109: 113-25. 
Kerr, Elenora (1917), The Effect of Wars and Revolutions on Government Securities, External and Internal, New York and Chicago: Imbrie.

Kothari, S. P. and J. B. Warner (2007), 'Econometrics of Event Studies', in B. Espen Eckbo (ed.),Handbook of Corporate Finance Empirical Corporate Finance, Amsterdam: Elsevier/North-Holland, pp. 3-36.

Lin, Chin-Tsai and Yi-Hsien Wang (2007), 'The Impact of Party Alternative on the Stock Market: The Case of Japan', Applied Economics, 39: 79-85.

McGillivray, Fiona (2003), 'Redistributive Politics and Stock Price Dispersion', British Journal of Political Science, 33(3): 367-95.

Niederhoffer, Victor, Steven Gibbs, and Jim Bullock (1970), 'Presidential Elections and the Stock Market', Financial Analysts Journal, 26: 111-13.

Nihon-Kikai-Kogyo-Rengokai [Association of Japanese Machine Industries] (2005), Buki-kin-yu Sangensoku-no Minaoshi-to Boei-kikai-sangyo-he-no Eikyo-chousa Houkokusyo [A Report on Relaxing the Three Arms Export Restiriction Policy and Effects to DefenceDefense-related Machine Industries], Tokyo: Nihon-Kikai-Kogyo-Rengokai and Japan Forum for Strategic Studies.

Oros, Andrew L. (2008), Normalizing Japan. Politics, Identity, and the Evolution of Security Practice, Stanford, CA: Stanford University Press.

Pekkanen, Saadia M. and Paul Kallender-Umezu (2010), In Defense of Japan: From the Market to the Military in Space Policy, Stanford, CA: Stanford University Press.

Schneider, Gerald and Vera E. Troeger (2006), 'War and the World Economy: Stock Market Reactions to International Conflicts, 1990-2000', Journal of Conflict Resolution, 50(5): 623-45.

Shinoda, Tomohito (2007), Koizumi Diplomacy: Japan's Kantei Approach to Foreign and DefenceDefense Affairs, Seattle: University of Washington Press.

Stigler, George J. and Claire Friedland (1962), 'What Can Regulators Regulate? The Case of Electricity', Journal of Law and Economics, 5(1): 1-16.

Zusman, Asaf and Noam Zusman (2006), 'Assassinations: Evaluating the Effectiveness of an Israeli Counterterrorism Policy Using Stock Market Data', Journal of Economic Perspectives, 20(2): 193-206. 